Article

\title{
Overview of the Main Disinfection Processes for Wastewater and Drinking Water Treatment Plants
}

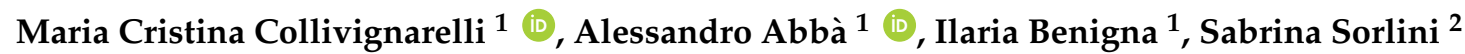 \\ and Vincenzo Torretta ${ }^{3, *}$ \\ 1 Department of Civil Engineering and Architecture, University of Pavia, via Ferrata 1, 27100 Pavia, Italy; \\ mcristina.collivignarelli@unipv.it (M.C.C.); abba78@unipv.it (A.A.); \\ ilaria.benigna01@universitadipavia.it (I.B.) \\ 2 Department of Civil, Environmental, Architectural Engineering and Mathematics, University of Brescia, \\ via Branze 43, 25123 Brescia, Italy; sabrina.sorlini@unibs.it \\ 3 Department of Theoretical and Applied Sciences, Insubria University of Varese, via G.B. Vico 46, \\ 21100 Varese, Italy \\ * Correspondence: vincenzo.torretta@uninsubria.it; Tel.: +39-0332-218-782
}

Received: 7 November 2017; Accepted: 27 December 2017; Published: 31 December 2017

\begin{abstract}
The use of water disinfection as a public health measure reduces the spread of diseases. Various disinfection technologies can be used to meet the pathogen inactivation demand in water. This work is an overview of the main disinfection technologies of wastewater and drinking water that reports for the conventional processes the action mechanism, the possible formation of by-products, the operative conditions, the advantages and disadvantages. For advanced and natural processes the action mechanisms are reported. Advanced technologies are interesting but are still in the research state, while conventional technologies are the most used. There is a tendency, especially in Italy, to use chlorine-based disinfectant, despite in some forms could lead to production of disinfection by-products.
\end{abstract}

Keywords: disinfection; toxicity; wastewater treatment; drinking water treatment

\section{Introduction}

The use of water disinfection as a public health measure reduces the spread of diseases. Various disinfection technologies can be used to meet the pathogen inactivation demand in water. Many of these chemical disinfectants if overdosed or used inappropriately can react with organic and inorganic precursors and bring the formation of disinfection by-products (DBPs) with adverse health effects.

The European Community's (EC) environmental regulations aim to sets standards for drinking water and to protect public health from the adverse effects of any contamination (Council Directive 98/83/EC) [1], while for wastewater aim to reduce the pollution of surface water [2,3] caused by municipal wastewater discharge (Council Directive 98/15/EC) [4]. Italian legislation (Decree Italian Law 152/2006 and following modifications) provides that wastewater treatment plants with a capacity higher than $2000 \mathrm{PE}$ (population equivalent), with the exclusion of treatment plants that apply natural technologies such as constructed wetlands or lagoons, must be equipped with a disinfection phase [5]. Disinfection is used in case of emergencies related to health risk situations or to ensure the achievement of the environmental quality objectives.

Drinking water regulations provide that drinking water treatment plants must be equipped with a disinfection phase when surface water is used $[5,6]$.

With the use of chemical disinfectants, residues of the compounds used and/or their DBPs can be found in the treated water that may have a toxic effect on humans and the aquatic environment. 
Aim of this work is exploring the disinfection technologies applied in drinking water treatment plants (DWTPs) and in wastewater treatment plants (WWTPs). This work consists of three parts: the first section reports the conventional processes applied on full scale; while the second one presents the advanced processes. In the third section the natural disinfection technologies are exposed. For conventional technologies, the following are examined: the action mechanisms; the possible formation of DBPs; the operative conditions, and; advantages and disadvantages. For advanced and natural processes the action mechanisms are reported.

\section{Disinfection Treatment}

To ensure microbiological quality disinfection treatment is of primary importance. Using disinfectants, pathogenic bacteria from the water can be killed and water made safe for the user [7].

The World Health Organization (WHO) provide the guidelines for drinking water quality in the protection of public health [8]. The guidelines provide the recommendations for managing the risk from hazards that may compromise the safety of drinking water and provide a scientific point of departure for national authorities to develop drinking water regulations and standards appropriate for the national situation. The guidelines are intended to support the development and implementation of risk management strategies that will ensure the safety of drinking water supplies through the control of hazardous constituents of water.

Securing the microbial safety of drinking-water supplies is based on the use of multiple barriers, from catchment to consumer, to prevent the contamination of drinking water or to reduce contamination to levels not injurious to health. Safety is increased if multiple barriers are in place, including protection of water resources, proper selection and operation of a series of treatment steps and management of distribution systems (piped or otherwise) to maintain and protect treated water quality. The preferred strategy is a management approach that places the primary emphasis on preventing or reducing the entry of pathogens into water sources and reducing reliance on treatment processes for removal of pathogens.

The Guidelines for Drinking Water Quality describe four distinct types of health-based targets, applicable to all types of hazards and water supplies:

- $\quad$ health outcome targets (e.g., tolerable burdens of disease);

- $\quad$ water quality targets (e.g., guideline values for chemical hazards);

- performance targets (e.g., log reductions of specific pathogens);

- $\quad$ specified technology targets (e.g., application of defined treatment processes) [8].

The quality assessment microbiological of water is based on the definition and the search for indicator organisms. In a quantitative microbial risk assessment it is not possible to consider all human enteric pathogens; therefore, reference pathogens are chosen that are of particular relevance to the exposure pathways and context of the individual risk assessment. Reference pathogens are intended to provide a conservative model for the risk assessment: if the reference pathogen is controlled, it is assumed that other important pathogens within each class would also be controlled.

When considering human enteric pathogens, at least one bacterium, one virus and one protozoan are typically recommended in order to cover the range of behaviors in the main enteric pathogen groups. Inclusion of a representative helminth (e.g., Ascaris) is recommended for wastewater reuse and sanitation-based scenarios.

Specific studies may require more detailed consideration of variability between pathogens within a particular group, in which case more than one reference organism should be selected (e.g., it may be relevant to model the highly chlorine-resistant oocysts from the parasitic protozoan Cryptosporidium alongside the less resistant but more numerous Giardia cysts in freshly contaminated waters). Both the GDWQ (Guidelines for Drinking Water Quality) [8] and the GWEG (Guidelines for the safe use of wastewater, excreta and greywater) [9] rely primarily on rotavirus, Campylobacter and Cryptosporidium as reference pathogens. 
However, the guidelines recommend that local considerations need to be accounted for, including the following:

- the epidemiological information on disease prevalence and outbreaks via the local water pathway(s);

- scientific evidence on pathogen persistence and infectivity;

- $\quad$ severity of disease outcomes [10].

The choice of indicators is used to determine the microbiological quality of water environments. The use of indicator organisms doesn't allow a direct estimation of the presence of a pathogenic microorganisms in the aquatic environment; it allows, rather, the rating of the probability that it will be present.

The EPA (Environmental Protection Agency) RWQC (Recreational Water Quality Criteria) recommend using the bacteria Enterococci and E. coli as indicator organisms for freshwater. Interestingly, many of the states have used the EPA RWQC as the basis for the reuse of wastewater.

The reuse of wastewater has positive benefits such as: improved agricultural production; reduced energy consumption associated with production, treatment, and distribution of water; there are also significant environmental benefits, such as reduced nutrient loads to receiving waters due to reuse of the treated wastewater.

The key objective is to achieve a quality of reclaimed water that is appropriate for the intended use and is protective of human health and the environment [11]. Regarding the microbiological quality of drinking water, the standards currently in force in Italy take as indicator the Enterococchi and Escherichia coli [6]. On the other hand, for wastewater the standards currently in force in Italy take as the single indicator of faecal pollution the Escherichia coli [5].

The factors to be considered in choosing the disinfection treatment are [12]:

- the water characteristics (type and concentration of microorganisms);

- the effluent final quality;

- the disinfectant agent toxicity;

- the disinfection by-products formation;

- plants characteristics (WWTPs and DWTPs);

- costs.

Moreover, the disinfection efficiency is affected by several interferences, such as ferrous and manganese ions, nitrites, sulphides and organic substances, that reduce the concentration of oxidizing disinfectants with the consequent reduction of microorganisms inactivation [13].

In order to evaluate the performance of the disinfection process is very important to consider the logarithmic removal rates. Table 1 shows the logarithmic removal rates for various human enteric pathogens with different disinfection processes. 
Table 1. Indicative $\log _{10}$ removals of enteric pathogens and indicator organism [14].

\begin{tabular}{|c|c|c|c|c|c|c|}
\hline Treatment & E. coli & $\begin{array}{l}\text { Bacterial Pathogens } \\
\text { (Including } \\
\text { Campylobacter) }\end{array}$ & $\begin{array}{c}\text { Viruses (Including } \\
\text { Adenoviruses, Rotaviruses } \\
\text { and Enteroviruses) }\end{array}$ & Giardia & Cryptosporidium & $\begin{array}{l}\text { Clostridium } \\
\text { Perfringens }\end{array}$ \\
\hline Chlorination & $2.0-6.0$ & $2.0-6.0$ & $1.0-3.0$ & $0.5-1.5$ & $0.0-0.5$ & $1.0-2.0$ \\
\hline Ozonation & $2.0-6.0$ & $2.0-6.0$ & $3.0-6.0$ & N/A & N/A & $0-0.5$ \\
\hline $\begin{array}{l}\text { Ultraviolet }(\mathrm{UV}) \\
\text { radiation }\end{array}$ & $2.0->4.0$ & $2.0->4.0$ & $\begin{array}{l}\quad>1.0 \text { adenovirus; }>3.0 \\
\text { enterovirus, hepatitis A virus }\end{array}$ & $>3.0$ & $>3.0$ & N/A \\
\hline $\begin{array}{l}\text { Membrane } \\
\text { filtration }\end{array}$ & $3.5-6.0$ & $3.5->6.0$ & $2.5->6.0$ & $>6.0$ & $>6.0$ & $>6.0$ \\
\hline Reverse osmosis & $>6.0$ & $>6.0$ & $>6.0$ & $>6.0$ & $>6.0$ & $>6.0$ \\
\hline Lagoon storage & $1.0-5.0$ & $1.0-5.0$ & $1.0-4.0$ & $3.0-4.0$ & $1.0-3.5$ & N/A \\
\hline $\begin{array}{l}\text { Wetlands-surface } \\
\text { flow }\end{array}$ & $1.5-2.5$ & 1 & $\mathrm{~N} / \mathrm{A}$ & $0.5-1.5$ & $0.5-1.0$ & 1.5 \\
\hline $\begin{array}{l}\text { Wetlands-subsurface } \\
\text { flow }\end{array}$ & $0.5-3.0$ & $1.0-3.0$ & $\mathrm{~N} / \mathrm{A}$ & $1.5-2.0$ & $0.5-1.0$ & $1.0-3.0$ \\
\hline
\end{tabular}

In this work the disinfection treatments are divided in conventional, advanced and natural processes. The conventional technologies include chlorine, chlorine dioxide, ozone, peracetic acid and ultraviolet (UV) radiation. The advanced technologies include the combination of ozone and hydrogen peroxide, of ozone and UV radiation, of hydrogen peroxide and UV radiation, of UV radiation with titanium dioxide, membranes technologies, and processes that are being studied. Finally, the natural disinfection technologies (slow sand filtration, infiltration/percolation in the soil, wastewater stabilization ponds and constricted wetlands) are exposed.

\subsection{Conventional Technologies}

Conventional technologies are the most widely used processes for disinfection of water. They are classified into chemical processes, including chlorine, chlorine dioxide, ozone and peracetic acid. In addition to chemical disinfectants, UV radiation has been used for many years for disinfection in wastewater treatment.

This section treats the different conventional disinfectants, their action mechanisms, the by-products formation and operative conditions.

\subsubsection{Action Mechanisms}

Chlorine is the most widely used disinfectant for the inactivation of waterborne pathogens in water treatment in the form of gaseous chlorine, chloramines and, above all, sodium hypochlorite [15]. The influencing factors are temperature, $\mathrm{pH}$ and organic content in the water. When chlorine gas is dissolved in water, it rapidly hydrolyzes to hydrochloric acid $(\mathrm{HCl})$ and hypochlorous acid $(\mathrm{HOCl})[16]$ :

$$
\mathrm{Cl}_{2}+\mathrm{H}_{2} \mathrm{O} \leftrightarrow \mathrm{H}^{+}+\mathrm{Cl}^{-}+\mathrm{HOCl}
$$

Chlorine has a powerful bactericidal action through the "blockage" of vital activities, with rather complex mechanisms. The main action of chlorine is to modify the chemical structure of the enzymes that are the basis of the mechanisms of nutrition of bacteria, inactivating them and thus inhibiting their development and life.

Chlorine dioxide is another bactericidal agent whose disinfectant power is equal to or higher than chlorine. Chlorine dioxide is a yellow-green gas with a pungent smell, water-soluble, but very unstable.

It is usually produced by sodium hypochlorite and hydrochloric acid according to the reaction:

$$
5 \mathrm{NaClO}_{2}+4 \mathrm{HCl} \rightarrow 4 \mathrm{ClO}_{2}+5 \mathrm{NaCl}+2 \mathrm{H}_{2} \mathrm{O} .
$$

Chlorine dioxide is characterized by high oxidizing power, which is the cause of its high germicidal potential. Due to the high oxidative power, possible bacterial elimination mechanisms may include inactivation of enzymatic systems or interruption of protein synthesis [17]. 
Ozone is an unstable gas produced by the dissociation of oxygen molecules in atomic oxygen. Ozone production can be done by electrolysis, photolytic reactions, and by radiochemical reaction induced by electric shocks. It is a highly unstable gas that, when produced, is rapidly discharged according to the reaction:

$$
\mathrm{O}_{3} \rightarrow \mathrm{O}_{2}+\mathrm{O}
$$

Ozone is an extremely reactive oxidizing agent characterized by disinfection efficiencies higher than the disinfection with chlorine [18]. The bactericidal power is generally attributed to the ability to destroy the cell wall of the microorganisms.

Ozonation also provides a significant reduction of UV absorbance and color, which can be an advantage for some reuse applications [19]. Furthermore ozonation is a promising technology for enhanced wastewater treatment to eliminate various organic micropollutants [20].

Peracetic acid is a feasible alternative to wastewater chlorination [21]. Peracetic acid (PAA) is produced by the reaction between hydrogen peroxide $\left(\mathrm{H}_{2} \mathrm{O}_{2}\right)$ and acetic acid $\left(\mathrm{CH}_{3} \mathrm{COOH}\right)$. During use the PAA decomposes, resulting the formation of acetic acid and oxygen.

The use of peracetic acid causes an increase of BOD (Biochemical Oxygen Demand) and COD (Chemical Oxygen Demand) on the final effluent resulting from the formation of acetic acid in solution.

The disinfecting action of PAA is due to the release of active oxygen or the production of reactive hydroxyl radicals that attack the bacterial cell causing cell wall and membrane destruction as well as certain enzymes and DNA [22-24].

Recently the combination between peracetic acid and UV radiation resulted very efficient $[25,26]$.

The ultraviolet radiation (UV) includes electromagnetic radiations between the X-rays and visible light in the range of $\lambda$ from 100 to $400 \mathrm{~nm}$. The germicidal UV-ray portion falls in the range 220-320 nm. The generation of UV rays is carried out by means of lamps containing mercury vapors produced through an electric arc. The energy generated by the excitation of mercury vapors contained within the lamp results in the emission of UV radiation [27].

The radiation penetrates the cell wall of the microorganisms and is absorbed by the nucleic acids causing the inhibition of replication and the death of the cells [28].

The effectiveness of UV radiation for disinfecting high quality secondary or tertiary treated effluents has been demonstrated [29-31]. The efficiency of UV disinfection can be influenced by suspended particles, particle sizes, or concentrations of dispersed microorganisms [32].

UV disinfection technology results very effective against the (oo)cyst of Cryptosporidium and Giardia, two pathogenic microorganisms of major importance for the safety of drinking water [33].

\subsubsection{By-Products Formation}

Disinfection processes can result in the formation of both organic and inorganic disinfection by-products (DBPs) [34].

Chlorine, in presence of natural organic substances, produces trihalomethane and acetoacetic, known to be carcinogenic to humans [35-42].

The trihalomethanes (THMs) are generally the most prevalent. These are a volatile group of compounds, which comprises chloroform, bromodichloromethane (BDCM), chlorodibromomethane (CDBM), and bromoform.

Chlorine reacts with natural organic compounds (such as humic and fulvic acids) to form a wide range of unwanted halogenated organic compounds including THMs, haloacetic acids (HAAs), chlorophenols, chloral hydrate, and haloacetonitriles (HANs).

Chloroform is usually the most prevalent by-product formed, although brominated THMs can occur at high concentrations when waters with high bromide concentrations are chlorinated.

Most other DBPs occur at trace concentrations (usually $<1 \mu \mathrm{g} \mathrm{L}{ }^{-1}$ ) [43].

The disinfection of water containing dimethylamine with chlorine leads to the formation of NDMA (N-nitrosodimethylamine). The concentration of NDMA is closely related to the ratio of chlorine, ammonia ions and dimethylamine [44]. 
During disinfection with chlorine dioxide, chlorite $\left(\mathrm{ClO}_{2}{ }^{-}\right)$and chlorate $\left(\mathrm{ClO}_{3}{ }^{-}\right)$are the major reaction by-products, potentially toxic. It is believed that the degradation of the residual chlorine dioxide and other final reaction products is faster than that observed in the case of chlorine and therefore these compounds should not represent a hazard to the aquatic environment [45].

During the disinfection with ozone, the formation of organic (e.g., aldehydes, carboxylic acids, and ketones) and inorganic (e.g., bromate) disinfection by-products has been well documented [46-53]. Ozone does not cause the formation of chlorinated by-products such as trihalomethane, but recent studies indicate that ozone induce the formation of NDMA [54-56].

The PAA dosage to the water causes the formation of aldehydes at very low concentrations $\left(<30 \mathrm{mg} \mathrm{L}^{-1}\right)$. The aldehyde formation is directly proportional to the peracetic acid dosage. The aldehydes formation varies with PAA/COD ratio, reaching a maximum around $0.3 \mathrm{mg} \mathrm{PAA} / \mathrm{mg}$ $\mathrm{COD}$ and then tending to vanish [57]. After initial increase ( $<20 \mathrm{~min})$, aldehydes formation starts to decrease and finally disappears in agreement with Chiang et al.'s two-step "formation and destruction" reaction mechanism [58].

The disinfection with UV radiation does not cause a formation of by-products [28].

Table 2 shown the advantages, the disadvantages, the actions spectrum and the applications of conventional disinfectants.

Table 2. Conventional disinfection technologies against different microbial groups $[59,60]$.

\begin{tabular}{|c|c|c|c|}
\hline $\begin{array}{l}\text { Conventional } \\
\text { Technologies }\end{array}$ & Advantages & Disadvantages & Application \\
\hline Chlorine & $\begin{array}{c}\text { Easy to handle and } \\
\text { economical; } \\
\text { Residual concentration; } \\
\text { Technologies consolidated }\end{array}$ & $\begin{array}{c}\text { High contact time; } \\
\text { By-product formation; } \\
\text { Residual toxicity of the effluent; } \\
\text { Very corrosive }\end{array}$ & $\begin{array}{l}\text { Drinking water; } \\
\text { Wastewater }\end{array}$ \\
\hline Chlorine dioxide & $\begin{array}{l}\text { More effective than chlorine } \\
\text { over short contact; } \\
\text { Long residual }\end{array}$ & $\begin{array}{c}\text { Residual toxicity of the effluent; } \\
\text { By-product formation; } \\
\text { Generation onsite; } \\
\text { Medium-high management costs; } \\
\text { Increase the concentration of solids in the effluent }\end{array}$ & $\begin{array}{l}\text { Drinking water; } \\
\text { Wastewater }\end{array}$ \\
\hline Ozone & Short contact time & $\begin{array}{l}\text { No residues of disinfectant; } \\
\text { By-product formation; Generation onsite; } \\
\text { High energy demand; } \\
\text { High management costs }\end{array}$ & Wastewater \\
\hline Peracetic acid & $\begin{array}{c}\text { Simple solution; } \\
\text { Residual concentration }\end{array}$ & $\begin{array}{c}\text { Increase BOD and COD concentration in } \\
\text { the effluent; } \\
\text { By-product formation }\end{array}$ & Wastewater \\
\hline UV radiation & $\begin{array}{l}\text { No by-products formation; } \\
\text { Short contact time; } \\
\text { Inactivation of virus }\end{array}$ & $\begin{array}{c}\text { No residues; } \\
\text { High energy demand; } \\
\text { High cost; } \\
\text { Unsuitable for water with high levels of } \\
\text { suspended solids, turbidity, color or soluble } \\
\text { organic matter }\end{array}$ & Wastewater \\
\hline
\end{tabular}

Water disinfection is a treatment aimed at reducing the presence of pathogenic microorganisms in the water, with a variable removal rates, as shown in Table 3. In particular, the CT (CT value is the product of the concentration of disinfectant agent in the water and the time of contact) values for $99 \%(2-\log )$ and $99.99 \%(4-\log )$ inactivation of bacteria and viruses for various disinfectant agents are reported.

The concept of disinfectant concentration and contact time is important to the understanding of disinfection kinetics and the practical application of CT concept (which is defined as the product of the residual disinfectant concentration $\mathrm{C}$, expressed in $\mathrm{mg} \mathrm{L}^{-1}$, and the contact time $\mathrm{T}$, expressed in minutes, that residual disinfectant is in contact with water) is important. CT value represents an operative parameter and it is an indicator of the effectiveness of the disinfection process. 
Table 3. Disinfectant dosage for bacteria and viruses inactivation [60].

\begin{tabular}{cccccc}
\hline \multirow{2}{*}{$\begin{array}{c}\text { Disinfectant } \\
\text { Agent }\end{array}$} & \multirow{2}{*}{$\begin{array}{c}\text { Measurement } \\
\text { Unit }\end{array}$} & \multicolumn{2}{c}{ Bacteria Inactivation } & \multicolumn{2}{c}{ Viruses Inactivation } \\
\cline { 3 - 6 } & 2-log & 4-log & 2-log & 4-log \\
\hline Chlorine & $\left({\left.\mathrm{mg} \mathrm{min} \mathrm{L}^{-1}\right)}^{\text {Chlorine }}\right.$ & $0.1-0.2$ & $10-12$ & $2.5-3.5$ & $6-7$ \\
dioxide & $\left(\mathrm{mg} \mathrm{min}^{-1}\right)$ & $8-10$ & $50-70$ & $2-4$ & $12-20$ \\
Ozone & $\left(\mathrm{mg} \mathrm{min} \mathrm{L}^{-1}\right)$ & $3-4$ & - & $0.3-0.5$ & $0.6-1.0$ \\
UV radiation & $\left(\mathrm{mJ} \mathrm{cm}^{-2}\right)$ & $30-60$ & $80-100$ & $20-30$ & $70-90$ \\
\hline
\end{tabular}

\subsubsection{Operative Conditions}

The sodium hypochlorite dosing system consists of a pump and a storage tank. Adequate mixing and contact time must be provided after injection to ensure complete disinfection of pathogens. It may be necessary to control the $\mathrm{pH}$ of the water [61].

Chlorination with sodium hypochlorite is a relatively simple and cost effective process, which does not require extensive technical expertise and which is capable of dealing with supply systems of varying size by altering dosing systems or storage for chemical contact accordingly [62].

Sodium hypochlorite solution is diluted with water in a mixing/holding tank. The diluted solution is injected by a chemical pump into the water supply pipe at a controlled rate. Adequate mixing and contact time must be provided [61].

Chlorine dioxide in unstable and it not be stored, but must be produced directly on site and only after the production is added to water [63]. Chlorine dioxide can produced by using sodium chlorine combined with hydrochloric acid or chlorine gas.

Ozone is unstable and therefore must be generated in situ. Ozonation equipment includes air preparation equipment (ozone generator, contactor, destruction unit), instrumentation and controls. The capital costs of ozonation systems are relatively high. Operation and maintenance are relatively complex. Electricity represents 26 to $43 \%$ of the total operating and maintenance costs for small systems [61].

In disinfection with PAA the plants are very simple, similar to the storage and dosing systems of sodium hypochlorite [63].

The effectiveness of UV radiation disinfection depends on the energy dose absorbed by the organism, measured as the product of the lamp's intensity (the rate at which photons are delivered to the target), the time of exposure, the color and turbidity of water. If the energy dose is not high enough, the organism's genetic material might only be damaged instead of destroyed. To provide a safety factor, the dose should be higher than needed to meet disinfection requirements.

Table 4 contains the operative conditions of conventional processes.

Table 4. Operative conditions of conventional technologies [63].

\begin{tabular}{|c|c|c|c|c|c|c|}
\hline $\begin{array}{l}\text { Conventional } \\
\text { Technologies }\end{array}$ & Chlorine Gas & $\begin{array}{l}\text { Sodium } \\
\text { Hypochlorite }\end{array}$ & Chlorine Dioxide & Ozone & $\begin{array}{l}\text { Peracetic } \\
\text { Acid }\end{array}$ & UV Radiation \\
\hline Capacity & all * & all & medium-high & medium-high & all * & all \\
\hline $\begin{array}{l}\text { Production and } \\
\text { storage system }\end{array}$ & simple & - & $\begin{array}{c}\text { complex } \\
\text { (generation on site) }\end{array}$ & $\begin{array}{c}\text { complex } \\
\text { (generation on site) }\end{array}$ & simple & - \\
\hline Maintenance & low & low & moderate & frequent & moderate & moderate/frequent \\
\hline $\begin{array}{c}\text { Staff } \\
\text { risks/competence }\end{array}$ & high & low & low-medium & high & high & high \\
\hline Investment costs & low & low & medium & very high & low & high \\
\hline $\begin{array}{l}\text { Management } \\
\text { costs }\end{array}$ & low & low & medium & high & medium & medium \\
\hline
\end{tabular}

Note: * these chemical agents could be used for plant with all capacity, but the high risks for staff and the high competence required reduce the field of use. 


\subsubsection{Acute Toxicity}

Wastewater treatment plants should maintain a certain residual in the wastewater to ensure bacterial die-off during chemical disinfection. Because disinfection is the last process in a WWTP before discharge, the residual gets transferred with the treated discharge. Residuals of the oxidizing disinfectants have long been known to be toxic to aquatic life in the receiving body of water [64].

A recent study demonstrates that chlorine and PAA residuals cause acute toxicity during disinfection. In particular, with values of residual disinfectant higher than 0.18 for free chlorine, and $2 \mathrm{mg} \mathrm{L}^{-1}$ for PAA, acute toxicity on Daphnia magna, Vibrio fischeri and/or Pseudokirchneriella subcapitata has occurred [65].

\subsection{Advanced Oxidation Processes}

In this section, the advanced oxidation processes (AOPs) that can be used for the final phase of DWTPs or WWTPs are reported. Despite the AOPs are generally used for the oxidation of a wide range and variety of organic and inorganic compounds, they can be apply for the water disinfection.

\subsubsection{Chemical Agents Combined with UV Radiation}

Advanced oxidation processes (AOPs) are treatments that aim to chemically destroy a contaminant, with the formation of reaction reactants with high reactivity, such as $\mathrm{OH} \bullet$ radicals, that can be obtained by simultaneously applying different oxidants: ozone; hydrogen peroxide; radiation $\mathrm{UV}$, and; peracetic acid.

AOPs are a very effective treatment technology since they can simultaneously degrade recalcitrant organic compounds and biological contaminants [66].

There is a frequent debate on the role of $\mathrm{OH} \bullet$ on pathogen disinfection. Some authors have stated that $\mathrm{OH} \bullet$ are not effective against Giardia muris, while others have suggested that $\mathrm{OH} \bullet$ play an important role in inactivation of E. coli and Bacillus subtilis spores. OH• produced in a photocatalytic disinfection process have been found to provide residual effects that repress the post-UV reactivation of coliform bacteria [67].

Traditional water disinfection treatment processes such as ozonation and UV disinfection can easily be retrofitted to accomplish advanced oxidation in both water and wastewater treatment plants.

The main applications in the treatment of water oxidation and disinfection are:

- $\quad$ ozone with hydrogen peroxide;

- $\quad$ ozone with UV radiation;

- hydrogen peroxide with UV radiation;

- UV radiation with titanium dioxide.

Advanced oxidation processes have advantages over conventional disinfection treatments such as, for example, not generating disinfection by-products [68]. Nevertheless, the common disadvantage shared between all AOPs is the high operating cost, which has somewhat limited large-scale application of this otherwise very powerful technology. However, with the introduction of higher efficiency UV lamps, visible light catalysts, and improved reactor design, with the help of computational fluid dynamics and energy modeling, both UV and solar-based photocatalysis have great potential for large-scale application [69].

\subsubsection{Ozone with Hydrogen Peroxide}

The oxidation process combined with ozone and hydrogen peroxide (peroxone) is among the most used for water treatment.

Hydrogen peroxide decomposes according to the following reaction:

$$
\mathrm{H}_{2} \mathrm{O}_{2}+\mathrm{H}_{2} \mathrm{O} \rightarrow \mathrm{HO}_{2}^{-}+\mathrm{H}_{3} \mathrm{O}^{+} .
$$


The $\mathrm{HO}_{2}{ }^{-}$reaction with ozone generates a sequence of chain reactions leading to the formation of $\mathrm{OH} \bullet$ radicals. The overall reaction of the formation of $\mathrm{OH} \bullet$ radicals is:

$$
\mathrm{H}_{2} \mathrm{O}_{2}+2 \mathrm{O}_{3} \rightarrow 2 \mathrm{OH} \bullet+2 \mathrm{O}_{2}
$$

Disinfection efficiency can be given for peroxide/ozone systems depending on the ozone residual remaining in the effluent water; this residual will decrease as the peroxide to ozone ratio increases [70].

The key difference between ozone and peroxone is in the primary oxidation mode; that is, direct oxidation or hydroxyl radical oxidation. The reactivity of these compounds creates a different effect in the reactions with water constituents and, thus, disinfection effectiveness.

Several studies showed that peroxone was comparable to ozone, or slightly more powerful, when CTs were based on ozone residuals. These results suggest that free radicals provide little benefit in terms of microbial destruction [71].

When the combination of ozone and hydrogen peroxide is used, the primary cause for pathogen inactivation is attributed to ozone, specifically the mechanisms associated with the oxidation of pathogens by direct ozone reaction and hydroxyl radicals.

Studies using ozone-hydrogen peroxide have shown that disinfection of $E$. coli is less effective as the peroxide to ozone ratio increases to above approximately $0.2 \mathrm{mg} \mathrm{mg}^{-1}$ [71]. The decrease in disinfection was probably due to the lower ozone residuals associated with higher peroxide to ozone ratios, which indicates that direct ozone reaction is an important mechanism for pathogen inactivation.

The results of a work that studied the inactivation of Giardia muris cysts (Table 5) suggest that peroxone is slightly more powerful than ozone: the $\mathrm{CT}$ values for ozone are greater than for peroxone. However, because ozone decomposes more rapidly in the presence of hydrogen peroxide, higher ozone dosages may be necessary with peroxone to achieve comparable residuals. Moreover, the use of ozone residuals to calculate CT products for peroxone may not take into account other oxidizing species that may have disinfectant capabilities [71].

Table 5. Disinfectant dosage for Giardia muris inactivation [71].

\begin{tabular}{cccc}
\hline \multirow{2}{*}{ Disinfectant Agent } & Measurement Unit & \multicolumn{2}{c}{ Giardia muris Inactivation } \\
\cline { 3 - 4 } & & 1-log & 2-log \\
\hline Ozone & $\left({\left.\mathrm{mg} \mathrm{min} \mathrm{L}^{-1}\right)}_{1.6-2.8}\right.$ & $3.4-5.4$ \\
Peroxone & $\left(\mathrm{mg} \mathrm{min} \mathrm{L}^{-1}\right)$ & $1.2-2.6$ & $2.6-5.2$ \\
\hline
\end{tabular}

\subsubsection{Ozone with UV Radiation}

Combination of ozone with UV radiation leads to the formation of radical reactions triggered by photochemical reaction between UV radiation and ozone both in gaseous phase and aqueous solution. Radicals, thanks to their high redox and low selectivity potential, are able to trigger more effective processes than using ozone only.

The ozone photolysis reaction in aqueous phase is:

$$
\mathrm{O}_{3}+\mathrm{H}_{2} \mathrm{O}+\mathrm{h} v \rightarrow \mathrm{O}_{2}+\mathrm{H}_{2} \mathrm{O}_{2}
$$

$\mathrm{h} v$ indicates UV radiation.

The production of radicals result from secondary reactions taking up hydrogen peroxide:

$$
2 \mathrm{O}_{3}+\mathrm{H}_{2} \mathrm{O}_{2} \rightarrow 2 \mathrm{OH} \bullet+3 \mathrm{O}_{2}
$$

From hydrogen peroxide photosynthesis:

$$
2 \mathrm{H}_{2} \mathrm{O}_{2}+\mathrm{h} v \rightarrow 2 \mathrm{OH} \bullet .
$$


As concerns the disinfection efficiency of this process, Fang et al., 2014 [67] showed that synergistic effects in E. coli inactivation were observed after the UV/ozone coexposure at ozone concentrations as low as $0.05 \mathrm{mg} \mathrm{L}^{-1}$ in ultrapure water. This synergistic effect occurred particularly at the initial stage of the coexposure: this aspect could be explained by the enhanced production of $\mathrm{OH} \bullet$ or other reactive especially during the initial coexposure but not at the later stage.

The UV/ozone coexposure achieved higher inactivation of E. coli than did the UV-ozone and ozone-UV sequential exposures, but the results of bacteriophage MS2 were the opposite. The synergistic effects were also found in tap water.

Moreover, Fang et al., 2014 [67] showed that combining UV with low-dose ozone can enhance disinfection efficiency and repress bacteria photoreactivation.

Other authors [72] report that the ozone/UV combination provides multiple barriers for Cryptosporidium and Giardia.

\subsubsection{Hydrogen peroxide with UV radiation}

The use of a low-pressure mercury lamp on water containing hydrogen peroxide leads to the $\mathrm{H}_{2} \mathrm{O}_{2}$ photolysis reaction; this reaction, essentially related to the absorption of a radiation emitted at $253.7 \mathrm{~nm}$, is [73]:

$$
\mathrm{H}_{2} \mathrm{O}_{2}+\mathrm{h} v \rightarrow 2 \mathrm{OH} \bullet \text {. }
$$

The radicals, produced by the reaction, can start a series of radical-chain reactions. The main factors that limiting the process efficiency are:

- the low molar absorption coefficient of $\mathrm{H}_{2} \mathrm{O}_{2}$ which requires high concentrations of hydrogen peroxide to generate $\mathrm{OH} \bullet$ radicals;

- $\quad \mathrm{H}_{2} \mathrm{O}_{2}$ can function as a scavenger against $\mathrm{OH} \bullet$ radicals $\left(\mathrm{OH} \bullet+\mathrm{H}_{2} \mathrm{O}_{2} \rightarrow \mathrm{H}_{2} \mathrm{O} \bullet+\mathrm{H}_{2} \mathrm{O}\right)$ so high concentrations of $\mathrm{H}_{2} \mathrm{O}_{2}$ can reduce process efficiency [74].

Despite many studies report that the $\mathrm{H}_{2} \mathrm{O}_{2} / \mathrm{UV}$ is effective for the destruction of various pollutants such as pesticides and pharmaceuticals, few available reports show the inactivation of microorganisms via $\mathrm{OH}$ radical oxidation.

Mamane et al. (2007) [75] showed that the addition of $\mathrm{H}_{2} \mathrm{O}_{2}\left(\right.$ at $25 \mathrm{mg} \mathrm{L}^{-1}$ ) in the presence of filtered UV irradiation over a 15 min reaction time did not result in any additional disinfection of bacteriophage T4, while an additional 1-log inactivation for bacteriophage T7 and 2.5-log for bacteriophage MS2 were obtained. As concerns the E. coli inactivation, only a slight additional effect was observed when $\mathrm{H}_{2} \mathrm{O}_{2}$ /UV was applied.

Other authors [76] have investigated the $\mathrm{H}_{2} \mathrm{O}_{2} / \mathrm{UV}$ disinfection efficiency. They observed that the combined $\mathrm{H}_{2} \mathrm{O}_{2} / \mathrm{UV}$ disinfection only slightly influenced the microbial reductions compared to $\mathrm{UV}$ treatments and showed some antagonism and no synergies. In particular, the combined $\mathrm{H}_{2} \mathrm{O}_{2} / \mathrm{UV}$ treatments showed statistically significant antagonistic effects for $E$. faecalis and non-significant synergy for MS2 coliphage [76]. Furthermore, at a cost parity for PAA/UV advanced oxidation process has the same disinfectant action than $\mathrm{H}_{2} \mathrm{O}_{2} / \mathrm{UV}$.

The efficiency of $\mathrm{H}_{2} \mathrm{O}_{2} / \mathrm{UV}$ depends on the microorganism and water type. These results indicate that for an UV based AOP process, the disinfection due to the presence of $\mathrm{OH}$ radicals is very small compared to the damage from the UV irradiation, although for viruses, there may be some oxidative enhancements that can assist disinfection efficacy [75].

Kruithof et al. (2007) [77] have studied $\mathrm{H}_{2} \mathrm{O}_{2} / \mathrm{UV}$ treatment for both primary disinfection and organic contaminant control in DWTPs. They proposed to apply this process before the GAC filtration in order to obtain a removal of residual $\mathrm{H}_{2} \mathrm{O}_{2}$.

Recently the combination with solar irradiation and $\mathrm{H}_{2} \mathrm{O}_{2}$ has been studied; it can produce cell inactivation due to the higher $\mathrm{OH} \bullet$ generation caused by $\mathrm{H}_{2} \mathrm{O}_{2}$ photolysis at $\lambda<254 \mathrm{~nm}$, cellular membrane attack and intracellular ROS (reactive oxygen species) formation [78]. 


\subsubsection{UV Radiation with Titanium Dioxide}

Titanium dioxide excited with UV radiation can produce $\mathrm{OH} \bullet$ radicals through redox processes. The photocatalytic process most used ones include:

- the addition of powder catalyst in an aqueous solution;

- preparation of a catalyst-based film (sol-gel method), which is adhered to a support material.

The main parameters that influence the yield of the process are [79]:

- the amount of $\mathrm{TiO}_{2}$ used (higher dosages are higher yields);

- lamp type (wavelengths less than $400 \mathrm{~nm}$ are generally sufficient for process activation);

- UV intensity (yield increases with increasing intensity);

- rotation speed (in rotating reactors the yield increases at the rate of increase);

- concentration of bicarbonate ions (increase in alkalinity decreases efficiency).

$\mathrm{TiO}_{2}$ photocatalysis has been reported to kill microorganisms and is not expected to produce THMs when used to treat drinking water. A drawback to using $\mathrm{TiO}_{2}$ photocatalysis as a disinfectant for drinking water is the lack of a residual disinfectant to maintain disinfection throughout a municipal distribution system. Because the hydroxyl radicals formed by $\mathrm{TiO}_{2}$ photocatalysis are highly reactive and are short-lived in water, the DWTPs will probably need to use a secondary disinfectant, such as chlorine (in addition to $\mathrm{TiO}_{2} / \mathrm{UV}$ treatment), to maintain a residual disinfectant in the distribution system [80].

Many authors carried out studies to identify the effective disinfection factors, such as the $\mathrm{TiO}_{2}$ concentration, light intensity, and $\mathrm{pH}$.

Watts et al. (1995) [81] has investigated the photocatalytic inactivation of coliform bacteria and poliovirus I in secondary wastewater effluent. The results obtained with $0.25 \mathrm{~g} \mathrm{TiO}_{2} \mathrm{~L}^{-1}$ addition and the irradiation with a fluorescent light show that 150 and $30 \mathrm{~min}$ were required to achieve 2-log reduction of coliform bacteria and poliovirus I, respectively. Moreover, the photochemical removal of poliovirus I and coliform bacteria was unaffected by the $\mathrm{pH}$ of the solution (in the range tested: $5-8$ ).

Chai et al. (2000) [82] showed that the disinfection capability in the aspect of time using both $\mathrm{TiO}_{2}$ and UV light was more than 27 times as that by using only the UV. These authors have shown that the optimal $\mathrm{TiO}_{2}$ concentration and $\mathrm{UV}$ light intensity were $0.1 \mathrm{gTiO}_{2} \mathrm{~L}^{-1}$ and $50 \mathrm{~W} \mathrm{~m}^{-2}$; in these conditions the time required for the complete disinfection of $E$. coli was 2-3 min.

Cho et al. (2002) [83] studied the effect of $\mathrm{TiO}_{2}$ concentration on the survival ratio of E. coli: they showed that $0.1 \mathrm{wt} \% \mathrm{TiO}_{2}$ loading (equal to $0.1 \mathrm{~g} \mathrm{~L}^{-1}$ ) is sufficient to harvest all of the incident light and that there is no advantage in going beyond this catalyst loading.

As concerns the inactivation behaviors of MS2 phage and E. coli, Cho et al. (2005) [84] showed that these aspects, which are mediated by the hydroxyl radicals generated on the illuminated $\mathrm{TiO}_{2}$ surface, are quite different, depending on the kind of microorganism (MS2 phage or E. coli). It was found that the inactivation of MS2 phage was carried out predominantly through the action of the bulk phase free hydroxyl radical, but that $E$. coli was inactivated by both free and surface-bound hydroxyl radicals as a major path and by other $\mathrm{ROS}$ such $\mathrm{O}_{2} \bullet^{-}$and $\mathrm{H}_{2} \mathrm{O}_{2}$ as a minor path.

\subsubsection{Membrane Filtration}

The membrane technologies allow the separation through a physical barrier to the pollutants present in the water. With the passage through the membranes, there is almost complete remove of the bacteria, and partial viruses that however reach very high values in the case of ultrafiltration [85].

Membrane filtration is an effective method to remove particles, microorganisms and organic matter from drinking water and wastewaters. Compared with conventional treatment methods, membrane processes [86]: 
- can provide better quality water;

- minimize disinfectant demand;

- are more compact;

- provide easier operational control and less maintenance;

- generate less sludge.

The most used technologies are (Table 6)

- microfiltration $(0.1-10 \mu \mathrm{m})$ is able to ensure the removal of most bacteria and protozoa's cysts, while not providing adequate virus removal;

- ultrafiltration $(0.01-0.1 \mu \mathrm{m})$ that allows complete removal of bacteria, viruses and protozoa;

- nanofiltration $(0.001-0.01 \mu \mathrm{m})$ that is able to remove color, volatile organic compounds (VOC), pesticides, sulphates, phosphates and microcystins produced by many cyanobacteria species [87];

- reverse osmosis $(<0.001 \mu \mathrm{m})$ : it is necessary to provide some pre-treatment (flocculation, lime addition, sedimentation, rapid filtration or ultrafiltration) to reduce the content of colloidal substances, suspended solids and organic matter which may cause problems of fouling of membranes with consequent reduction of efficiency and operating flow [60].

Whereas nanofiltration and reverse osmosis processes are effective in removing protozoan (oo)cysts, microfiltration and ultrafiltration are the most commonly applied/used technologies for microbial removal because of their cost-effectiveness [88].

Table 6. Membrane technologies.

\begin{tabular}{|c|c|c|c|c|c|c|}
\hline \multirow[b]{2}{*}{ Technologies } & \multirow{2}{*}{$\begin{array}{l}\text { Porosity } \\
(\mu \mathrm{m})\end{array}$} & \multirow[b]{2}{*}{$\begin{array}{l}\text { Pressure } \\
\text { (bar) }\end{array}$} & \multirow[b]{2}{*}{ Removal } & \multicolumn{3}{|c|}{ Disinfection Efficiency (Log Reduction) } \\
\hline & & & & $\begin{array}{l}\text { E. coli and Fecal } \\
\text { coliform }\end{array}$ & $\begin{array}{l}\text { Giardia } \\
\text { Muris }\end{array}$ & $\begin{array}{c}\text { MS2 } \\
\text { Coliphages }\end{array}$ \\
\hline $\begin{array}{l}\text { Microfiltration } \\
\text { MF }\end{array}$ & $0.1-10$ & $1-5$ & $\begin{array}{c}\text { Suspended solids, } \\
\text { macromolecules, bacteria }\end{array}$ & $5.4-6$ & $>4-6$ & $0.3-2$ \\
\hline $\begin{array}{l}\text { Ultrafiltration } \\
\text { UF }\end{array}$ & $0.01-0.1$ & $1-7$ & $\begin{array}{c}\text { Macromolecules, viruses, } \\
\text { humic acids, } \\
\text { DBP precursors }\end{array}$ & $5.5->6$ & $>4-6$ & $0.4-2$ \\
\hline $\begin{array}{l}\text { Nanofiltration } \\
\text { NF }\end{array}$ & $0.001-0.1$ & $5-10$ & $\begin{array}{l}\text { Color, VOC, pesticides, } \\
\text { MTBE (Methyl tert-butyl } \\
\text { ether), sulphates, } \\
\text { phosphates }\end{array}$ & $\mathrm{N} / \mathrm{A}$ & $\mathrm{N} / \mathrm{A}$ & $2-3$ \\
\hline $\begin{array}{c}\text { Reverse } \\
\text { osmosis RO }\end{array}$ & $<0.001$ & $15-70$ & $\begin{array}{l}\text { Metal ions, metals } \\
\text { (arsenic, lead) }\end{array}$ & $\mathrm{N} / \mathrm{A}$ & $\mathrm{N} / \mathrm{A}$ & $3.5-4.5$ \\
\hline References & \multicolumn{3}{|c|}{$[60,79,89]$} & [89] & [90] & {$[76,89,90]$} \\
\hline
\end{tabular}

Note: N/A: data not available. Disinfection by-product (DBP); volatile organic compound (VOC).

The efficiency of the membranes depends on the water quality, the load of solids and the formation of fouling during the treatment. To reduce this problem, we can use systems combined with a low pressures membrane filtration followed by high pressures membrane filtration.

\subsubsection{Other Disinfectant: Research Experiences}

Table 7 shows experiences of experiments of advanced disinfection processes reported in international scientific literature. These research experiences are very heterogeneous both for the type of disinfectant and the type of water treated. 
Table 7. Other disinfectant [91-95].

\begin{tabular}{|c|c|c|c|c|c|c|c|c|c|}
\hline Type of Disinfection & Action Mechanism & Type of Effluent & Operative Conditions & \multicolumn{2}{|c|}{ Experimental Scale } & \multicolumn{3}{|c|}{ Results } & Ref. \\
\hline $\begin{array}{l}\text { UV+Peracetic acid } \\
\text { (PAA) }\end{array}$ & $\begin{array}{l}\text { UV produces a homolytic } \\
\text { rupture in the O-O bond of the } \\
\text { PAA molecule, with the } \\
\text { subsequent formation of the } \\
\text { hydroxyl radical }\end{array}$ & Urban wastewater & $\begin{array}{l}\text { PAA dosage: } 2-8 \mathrm{mg} \mathrm{L}^{-1} \\
\mathrm{t:} 10-30 \mathrm{~min} \\
\text { UV: } 100-300 \mathrm{~mJ} \mathrm{~cm}^{-2}\end{array}$ & \multicolumn{2}{|c|}{ Pilot plant } & \multicolumn{3}{|c|}{ E. coli: Total inactivation } & [91] \\
\hline Sonodisinfection & $\begin{array}{l}\text { Production of free radicals in the } \\
\text { bulk; shearing forces produced } \\
\text { by US cavitation; breakage of } \\
\text { bacteria agglomeration, that } \\
\text { favours the disinfection }\end{array}$ & Urban wastewater & $\begin{array}{l}\text { US: } 200 \mathrm{~W} \\
\text { Irrad. time: } 60 \mathrm{~min}\end{array}$ & \multirow{3}{*}{\multicolumn{2}{|c|}{ Bench scale }} & \multicolumn{3}{|c|}{ E. coli: $1-\log$} & [92] \\
\hline Electrodisinfection & $\begin{array}{l}\text { Hypochlorite and chloramines } \\
\text { production }\end{array}$ & & Current density: $11.46 \mathrm{~A} \mathrm{~m}^{-2}$ & & & \multicolumn{3}{|c|}{ E. coli: $3-\log$} & \\
\hline Sono-electrodisinfection & $\begin{array}{l}\text { Hypochlorite and chloramines } \\
\text { production }\end{array}$ & & $\begin{array}{c}\text { US: } 200 \mathrm{~W} \\
\text { Current density: } 8.91 \mathrm{~A} \mathrm{~m}^{-2}\end{array}$ & & & \multicolumn{3}{|c|}{ E. coli: $3-\log$} & \\
\hline Solar photolysis & \multirow{3}{*}{ Dimerization of DNA } & \multirow{3}{*}{$\begin{array}{c}\text { Drinking } \\
\text { water/wastewater }\end{array}$} & Irrad. time: $40 \mathrm{~min}$ & \multirow{3}{*}{\multicolumn{2}{|c|}{ Lab scale }} & \multicolumn{3}{|c|}{ E. coli: $1-\log$} & \multirow{3}{*}{ [93] } \\
\hline $\begin{array}{l}\text { Solar photocatalytic } \\
\text { (absence of HA) }\end{array}$ & & & $\begin{array}{l}\text { Irrad. time: } 60 \mathrm{~min} \\
\text { Dosage of dopants * }\end{array}$ & & & \multicolumn{3}{|c|}{ E. coli: 6-log } & \\
\hline $\begin{array}{l}\text { Solar photocatalytic } \\
\text { (presence of HA) }\end{array}$ & & & $\begin{array}{l}\text { Irrad. time: } 60 \mathrm{~min} \\
\text { Dosage of dopants }{ }^{* *} ; \\
\text { Irrad. time: } 90 \mathrm{~min} \\
\text { Dosage of dopant }\end{array}$ & & & \multicolumn{3}{|c|}{ E. coli: 6-log } & \\
\hline \multirow{2}{*}{$\begin{array}{l}\text { Combination of } \\
\text { ultrasound (US) and UV } \\
\text { radiation }\end{array}$} & \multirow{2}{*}{$\begin{array}{l}\text { Ultrasound destroys large } \\
\text { suspended particles and the UV } \\
\text { disinfection efficiency increases }\end{array}$} & \multirow{2}{*}{$\begin{array}{l}\text { Urban and } \\
\text { industrial } \\
\text { wastewater }\end{array}$} & $\begin{array}{l}\text { US: } 350 \mathrm{~W} \\
\text { UV: } 1656 \mathrm{~mJ} \mathrm{~cm}-2 \\
\text { t:15 min }\end{array}$ & \multirow{2}{*}{\multicolumn{2}{|c|}{ Pilot plant }} & \multicolumn{3}{|c|}{$\begin{array}{l}\text { E. coli: } 1.6-\log \\
\text { Total coliform: } 1.7-\log \end{array}$} & \multirow[t]{2}{*}{ [94] } \\
\hline & & & $\begin{array}{l}\text { US: } 1400 \mathrm{~W} \\
\text { UV: } 1656 \mathrm{~mJ} \mathrm{~cm}^{-2} \\
\text { t:15 min }\end{array}$ & & & \multicolumn{3}{|c|}{$\begin{array}{l}\text { E. coli: }>\text { 4-log } \\
\text { Total coliform: 3.9-log }\end{array}$} & \\
\hline \multirow{5}{*}{$\begin{array}{l}\text { Comparison between } \\
\text { UV continuous and UV } \\
\text { pulsed }\end{array}$} & \multirow{5}{*}{ DNA damage } & \multirow{5}{*}{ Wastewater } & & & \multirow{5}{*}{ Bench scale } & E. coli & Phage T4 & Phage T7 & \multirow{5}{*}{ [95] } \\
\hline & & & \multirow{4}{*}{$3 \mathrm{~mJ} \mathrm{~cm}^{-2}$} & $\mathrm{LP}(254 \mathrm{~nm}) \times 4$ & & 1.75-log & 2.55-log & $1.05-\log$ & \\
\hline & & & & MP $(200 \mathrm{~nm})$ & & 1.80-log & 2.67-log & 1.52-log & \\
\hline & & & & PUV > $295 \mathrm{~nm}$ & & $0.25-\log$ & $1.20-\log$ & $0.93-\log$ & \\
\hline & & & & PUV > $400 \mathrm{~nm}$ & & $0.08-\log$ & $0.49-\log$ & $0.52-\log$ & \\
\hline
\end{tabular}

Note: HA: humic acid; * 3 kinds of dopants are dosed: Se-doped TiO2, N-doped TiO2 and Se-N-co-doped TiO2; ** 2 kinds of dopants are dosed: Se-doped TiO2 and Se-N-co-doped TiO2; *** 1 kind of dopant is dosed: N-doped TiO2 t: contact time; Irrad. time: irradiation time; LP: low-pressure; MP: medium-pressure; PUV: pulsed UV. 


\subsection{Natural Disinfection}

\subsubsection{Slow sand Filtration}

The slow sand filtration (filtration rate of 3-8 $\mathrm{m} \mathrm{d}^{-1}$ ) utilizes the purifying action on a superficial biological film that forms on the filter medium, which can remove over 99\% (2-log reduction) of the microorganisms present in the influent (previously decanted or subjected to secondary biological treatment) without the need for any further treatment [96].

Slow sand filtration is one of the oldest water treatment process used to produce microbiologically safe water. Additional research was conducted [97-100] to collect more quantitative information.

\subsubsection{Porous Ceramic Water Filtration}

The most used filters (at household level) are made of porous natural materials that are easily accessible, such as clay, or its blending with inorganic materials such as ceramic. A ceramic filter can be simply obtained by the mixing of dry clay with organic material (such as coffee, tea leaves or rice shells) with the addition of water to obtain a rigid mixture. Ceramic filters are being produced in many parts of the world. Some of them are manufactured in developed or emerging countries under strict quality control constraints.

The ceramic filters are extensively tested for efficacy in reducing various waterborne microbial contaminants. The disinfection performance of ceramic filters with a pore size equal to $0.2 \mu \mathrm{m}$, in terms of $\log$ reduction, are the following [101]:

- $\quad$ E. coli: $>7.9$;

- Shigella dysenteriae: $>6.9$;

- Vibrio cholera: $>4.0$;

- Giardia lamblia: $>6.5$;

- Cryptosporidium parvum: $>3.0$;

- Entamoeba histolytica: $>5.9$.

\subsubsection{Infiltration/Percolation in the Soil}

This technique is very similar to slow filtration and consists in periodically distributing the effluent from a secondary treatment over a sand filtration layer (1.5-2 m thick). Periodic application makes filtration and percolation processes possible. As the effluent goes through the sand, the frequent presence of air in the sand layer maintains aerobic conditions.

With a sand filtration layer of $1.5 \mathrm{~m}$ and a hydraulic load between 0.15 and $0.35 \mathrm{~m} \mathrm{~d}^{-1}$, the removal of Fecal coliform is equal to 5-log and the Helminth eggs are totally removed [96].

\subsubsection{Managed Aquifer Recharge}

Managed aquifer recharge (MAR) is used for treating water for potable use and storing water for future needs by recharging the natural groundwater source. There are several methods used for MAR: aquifer storage and recovery (ASR); aquifer storage; transfer and recovery (ASTR); infiltration ponds; infiltration galleries; soil aquifer treatment; percolation tanks or recharge weirs; rainwater harvesting for aquifer storage; recharge releases; dry wells; bank filtration; dune filtration; underground dams, and; sand dams [102]. The main principle being that surface water from a lake or a river is by artificial means made to percolate or flow through porous material such as sand to recharge the groundwater [103].

The MAR method by basin infiltration was shown to have a high pathogen removal capacity in regard to bacteria and viruses. The microbiological barrier regarding virus was efficient in $4 \mathrm{~m}$ of unsaturated zone, 3-log, comparable with both disinfection with chlorine and chemical precipitation. For viruses the efficiency was higher in unsaturated zone compared to saturated zone. 
The microbiological barrier efficiency regarding bacteria was sufficient in $4 \mathrm{~m}$ of unsaturated zone, higher than 2.4-log, comparable to disinfection with chlorine and chemical precipitation. However, there was no obvious difference in efficiency between an unsaturated and a saturated condition.

The protozoa should be effectively removed because they are larger than bacteria; however, heterogeneity in the soil and the protozoan high survival suggests that this should not be taken for granted [103].

\subsubsection{Wastewater Stabilization Ponds}

This process consists of oxidation basins (depth $\mathrm{h}=1.5-2 \mathrm{~m}$ and retention time of $10-50 \mathrm{~d}$ ) working in series with an aerobic final stage $(\mathrm{h}=0.5-1 \mathrm{~m})$. Removal is due to different factors: food shortages, predation, algae adsorption, high $\mathrm{pH}$ values, solar radiation [96].

Elevated $\mathrm{pH}$ and dissolved oxygen concentrations, which are attributed to the presence of algae, are important factors for effective disinfection. Therefore, the presence of algae in natural wastewater treatment systems can contribute appreciably to disinfection. Consequently, based on algal concentrations, removal efficiencies of pathogenic microorganisms during wastewater treatment over the course of a year can be highly variable, where higher removal efficiencies would be expected in summer and fall seasons [104].

The reduction of bacteria helminth could reach 6-log and 3-log, respectively [96]. As concerns the virus, on average, 1-log reduction was achieved for every 14.5-20.9 days of retention [105].

\subsubsection{Constructed Wetlands}

The main factors responsible to reducing bacterial population are: physical processes such as mechanical filtration, sedimentation and adsorption; chemical processes such as the release of oxygen from plants and biological mechanisms such as natural death, predation and action of antibiotic substances released by macrophytes.

Gopal et al. (1993) [106] found that some acids such as tannic acid and Gallic acid are secreted from the roots of many aquatic plants and cause disinfection. In addition to this direct effect the development, in the rhizosphere, of populations of bacteria with antibiotic properties (e.g., Pseudomonas) may also contribute to the removal of Escherichia coli $[96,107]$.

The removal efficiency of Total and Fecal coliform in different subsurface flow wetland (typically constructed as a bed or channel containing appropriate media) that receive secondary wastewater effluent can reach 3-log reduction especially with Scirpus and Phragmites macrophytes [96].

\subsubsection{Solar Disinfection}

Sunlight is known to be a pertinent factor governing the infectivity of waterborne viruses in the environment. Sunlight inactivates viruses via endogenous inactivation (promoted by absorption of solar light in the UVB range by the virus) and exogenous processes (promoted by adsorption of sunlight by external chromophores, which subsequently generate inactivating reactive species).

The extent of inactivation is still difficult to predict, as it depends on multiple parameters including virus characteristics, solution composition, season and geographical location.

Endogenous inactivation is mediated by virus-internal chromophores, such as the nucleic acid or aromatic amino acids in the protein coat, which absorb light in the solar range. Upon light excitation, these internal chromophores can degrade and cause the virus to become inactivated. This process is referred to as direct inactivation. Alternatively, endogenous inactivation can occur in an indirect fashion. Hereby, the excited chromophores transfer energy or electrons to dissolved oxygen or other solution constituents, which leads to the formation of a variety of transient reactive species (e.g., singlet oxygen). Along with the excited chromophores themselves, these reactive species can then oxidize surrounding virus constituents and thereby cause inactivation. In indirect exogenous inactivation, reactive species are produced by virus-independent chromophores present in solution [108]. 
Another method for water disinfection by means of solar energy is the use of solar ponds. Solar ponds are dug into the ground, filled with water and covered with glazing (sheets of plastic or glass). Within the solar pool, the temperature reaches $63^{\circ} \mathrm{C}$ (very close to the pasteurization temperature of $65{ }^{\circ} \mathrm{C}$ ), thanks to the greenhouse effect of the glazing cover [109].

With temperature between 55 and $65^{\circ} \mathrm{C}$, it is possible to obtain inactivation yields of $90 \%(1-\log )$ for protozoa (Giardia, Cryptosporidium, Entamoeba), bacteria (V. cholerae, E. coli, Shigella, Salmonella Typhi) and viruses, with a $1 \mathrm{~min}$ exposure time. Instead, with $5 \mathrm{~min}$ exposure time, the inactivation yields can reach $99.99 \%(3-\log )$.

In order to obtain an effective bacterial inactivation, it is important to maintain an optimal saline gradient in all solar pond surface. This value is still being studied, through the development and the implementation of different methodologies [109-111].

\section{Conclusions}

An overview of the main disinfection processes for wastewater and drinking water was presented in this work. Despite the availability of many disinfection processes based on different action mechanisms, the conventional processes, which are consolidated technologies, represent the most used treatments. Nowadays, chlorine-based disinfectants are commonly used in Italy (mainly due to their efficiency, low cost and easy use), despite the fact that they may bring by-products to the disinfection process.

The natural disinfection processes could represent valuable solutions, due in particular to the absence of chemical reagents. Moreover, the advanced technologies are very interesting but they are still in the research state. Several strategies aiming to avoid or reduce the use of chemical reagents (especially chlorine) have already been studied. Despite the advantages of these methods, several aspects (e.g., reliability and applicability to large-scale water treatment plant, costs, etc.) restrict the use of these technologies on an industrial scale.

In future perspectives, the role of disinfection treatment should be taken into account due to the control of emerging contaminants (i.e., protozoa, which are not currently regulated in Italy). Moreover, ongoing research will lead to a deeper knowledge in emerging contaminants and DBPs; thus, the use of alternative technologies, such as membrane filtration and UV-based processes, will increase.

Finally, the multi-step disinfection concept, that is, the application of disinfection process not only as final stage, could represent an interesting solution in order to reduce the production of DBPs and to improve the removal of microorganisms.

Author Contributions: Alessandro Abbà and Ilaria Benigna contributed to the drafting of the sections concerning the conventional disinfection technologies and the natural processes. Sabrina Sorlini contributed to the drafting of the advanced oxidation processes. Maria Cristina Collivignarelli and Vincenzo Torretta supervised the study and the paper drafting. All authors have read and approved the final manuscript.

Conflicts of Interest: The authors declare no conflict of interest.

\section{References and Note}

1. European Union. Directive 98/83/EC of 3 November 1998 on the Quality of Water Intended for Human Consumption; European Union: Brussels, Belgium, 1998.

2. Todeschini, S.; Papiri, S.; Sconfietti, R. Impact assessment of urban wet-weather sewer discharges on the Vernavola river (Northern Italy). Civ. Eng. Environ. Syst. 2011, 28, 209-229. [CrossRef]

3. Todeschini, S. Hydrologic and Environmental Impacts of Imperviousness in an Industrial Catchment of Northern Italy. ASCE's J. Hydrol. Eng. 2016, 21, 05016013. [CrossRef]

4. European Union. Directive 98/15/EC of 27 February 1998 Amending Council Directive 91/271/EEC with Respect to Certain Requirements Established in Annex I thereof (Text with EEA Relevance); European Union: Brussels, Belgium, 1998. 
5. Regulations on Environmental Matters; Decree Italian Law 152/2006. 2006. Available online: $\quad$ http://www.gazzettaufficiale.it/atto/serie_generale/caricaDettaglioAtto/originario?atto. dataPubblicazioneGazzetta=2006-04-14\&atto.codiceRedazionale=006G0171 (accessed on 30 December 2017).

6. Decree Italian Law 31/2001. Available online: http:/ /www.camera.it/parlam/leggi/deleghe/01031dl.htm (accessed on 30 December 2017).

7. Somani, S.B.; Ingole, N.W.; Kulkarni, N.S. Disinfection of water by using sodium chloride (NaCl) and sodium hypochlorite (NaOCl). J. Eng. Res. Stud. 2011, 2, 40-43.

8. World Health Organization. Guidelines for Drinking-Water Quality: Fourth Edition Incorporating the First Addendum; World Health Organization: Geneva, Switzerland, 2017; ISBN 978-92-4-154995-0.

9. Guidelines for the Safe Use of Wastewater, Excreta and Greywater. Vol. 4. Excreta and Greywater Use in Agriculture; World Health Organization: Geneva, Switzerland, 2006. Available online: http:/ / www.who.int/water_ sanitation_health/publications/gsuweg4/en/ (accessed on 30 December 2017).

10. World Health Organization. Quantitative Microbial Risk Assessment: Application for Water Safety Management; World Health Organization: Geneva, Switzerland, 2016; ISBN 978-92-4-156537-0.

11. U.S. Environmental Protection Agency. Guidelines for Water Reuse; U.S. Environmental Protection Agency: Washington, DC, USA, 2012.

12. Sorlini, S. "Uso irriguo e civile: Tecnologie avanzate per la disinfezione delle acque". Atti della 26a Giornata di Studio di Ingegneria Sanitaria-Ambientale "Il riutilizzo delle acque reflue-Aspetti impiantistici e gestionali" (April 2004).

13. Ivanov, V. Environmental Microbiology for Engineers; CRC Press: Boca Raton, FL, USA, 2011; ISBN 978-1-4200-9234-9.

14. National Water Quality Management Strategy (NWQMS). National Guidelines for Water Recycling: Managing Health and Environmental Risks; Report of the National Resource Management Ministerial Council, Environment Protection and Heritage Council and Australian Health Ministers' Conference; Department of Agriculture and Water Resources: Canberra, Australia, 2006; ISBN 1-921173-06-8.

15. Li, H.Y.; Osman, H.; Kang, C.W.; Ba, T. Numerical and experimental investigation of UV disinfection for water treatment. Appl. Therm. Eng. 2017, 111, 280-291. [CrossRef]

16. Lin, S.D. Water and Wastewater Calculations Manual; McGraw-Hill: New York, NY, USA, 2001; ISBN 0-07-137195-8.

17. Cho, M.; Kim, J.; Kim, J.Y.; Yoon, J.; Kim, J.-H. Mechanisms of Escherichia coli inactivation by several disinfectants. Water Res. 2010, 44, 3410-3418. [CrossRef] [PubMed]

18. Mezzanotte, V.; Antonelli, M.; Citterio, S.; Nurizzo, C. Wastewater Disinfection Alternatives: Chlorine, Ozone, Peracetic Acid, and UV Light. Water Environ. Res. 2007, 79, 2373-2379. [CrossRef] [PubMed]

19. Xu, P.; Janex, M.L.; Savoye, P.; Cockx, A.; Lazarova, V. Wastewater disinfection by ozone: Main parameters for process design. Water Res. 2002, 36, 1043-1055. [CrossRef]

20. Lee, Y.; von Gunten, U. Advances in predicting organic contaminant abatement during ozonation of municipal wastewater effluent: Reaction kinetics, transformation products, and changes of biological effects. Water Res. Technol. 2016, 2, 421-442. [CrossRef]

21. Rossi, S.; Antonelli, M.; Mezzanotte, V.; Nurizzo, G. Peracetic acid disinfection-A feasible alternative to wastewater chlorination. Water Environ. Res. 1997, 79, 341-350. [CrossRef]

22. Liberti, L.; Lopez, A.; Notarnicola, M. Disinfection with Peracetic Acid for Domestic Sewage Re-use in Agriculture. J. Water Environ. Manag. 1999, 13, 262-269. [CrossRef]

23. Lefevre, F.; Audic, J.M.; Ferrand, F. Peracetic acid disinfection of secondary effluents discharged off coastal seawater. Water Sci. Technol. 1992, 25, 155-164.

24. Kitis, M. Disinfection of wastewater with peracetic acid: A review. Environ. Int. 2004, 30, 47-55. [CrossRef]

25. Lubello, C.; Caretti, C.; Gori, R. Comparison between PAA/UV and $\mathrm{H}_{2} \mathrm{O}_{2} / \mathrm{UV}$ disinfection for wastewater reuse. Water Supply 2002, 2, 205-212.

26. Gori, R.; Caretti, C. Experimental study on municipal and industrial reclaimed wastewater refinement for agriculture reuse. Water Sci. Technol. 2008, 58, 217-223. [CrossRef] [PubMed]

27. Bonomo, L. Trattamenti Delle Acque Reflue; McGraw-Hill: New York, NY, USA, 2008; ISBN 978-88-386-6518-9.

28. Hijnen, W.A.M.; Beerendonk, E.F.; Medema, G.J. Inactivation credit of UV radiation for viruses, bacteria and protozoan (oo)cysts in water: A review. Water Res. 2006, 40, 3-22. [CrossRef] [PubMed] 
29. Oguma, K.; Katayama, H.; Mitani, H.; Morita, S.; Hirata, T.; Ohgaki, S. Determination of pyrimidine dimers in Escherichia coli and Cryptosporidium parvum during UV light inactivation, photoreactivation, and dark repair. Appl. Environ. Microbiol. 2001, 67, 4630-4637. [CrossRef] [PubMed]

30. Liltved, H.; Landfald, B. Effects of high intensity light on ultraviolet-irradiated and non-irradiated fish pathogenic bacteria. Water Res. 2000, 34, 481-486. [CrossRef]

31. Lee, O.M.; Kim, H.Y.; Park, W.; Kim, T.H.; Yu, S. A comparative study of disinfection efficiency and regrowth control of microorganism in secondary wastewater effluent using UV, ozone, and ionizing irradiation process. J. Hazard. Mater. 2015, 295, 201-208. [CrossRef] [PubMed]

32. Taghipour, F. Ultraviolet and ionizing radiation for microorganism inactivation. Water Res. 2004, 38, 3940-3948. [CrossRef] [PubMed]

33. Hijnen, W.A.M. Quantitative Methods to Assess Capacity of Water Treatment to Eliminate Microorganism; KWR Water Research Institute Series; IWA Publishing: London, UK, 2011; ISBN 184339376X.

34. Sadiq, R.; Rodriguez, M.J. Disinfection by-products (DBPs) in drinking water and predictive models for their occurrence: A review. Sci. Total Environ. 2004, 321, 21-46. [CrossRef] [PubMed]

35. Rebhun, M.; Heller-Grossman, L.; Manka, J. Formation of Disinfection Byproducts during Chlorination of Secondary Effluent and Renovated Water. Water Environ. Res. 1997, 69, 1154-1162. [CrossRef]

36. Sun, Y.-X.; Wu, Q.-Y.; Hu, H.-Y.; Tian, J. Effect of ammonia on the formation of THMs and HAAs in secondary effluent chlorination. Chemosphere 2009, 76, 631-637. [CrossRef] [PubMed]

37. Wu, M.N.; Wang, X.C.; Ma, X.Y. Characteristics of THMFP increase in secondary effluent and its potential toxicity. J. Hazard. Mater. 2013, 261, 325-331. [CrossRef] [PubMed]

38. Sorlini, S.; Biasibetti, M.; Gialdini, F.; Collivignarelli, M.C. How can drinking water treatments influence chlorine dioxide consumption and by-product formation in final disinfection? Water Sci. Technol. Water Supply 2016, 16. [CrossRef]

39. Sorlini, S.; Collivignarelli, M.C.; Canato, M. Effectiveness in chlorite removal by two activated carbons under different working conditions: A laboratory study. J. Water Supply Res. Technol. AQUA 2015, 64, 450-461. [CrossRef]

40. Badawy, M.I.; Gad-Allah, T.A.; Ali, M.E.M.; Yoon, Y. Minimization of the formation of disinfection by-products. Chemosphere 2012, 89, 235-240. [CrossRef] [PubMed]

41. Guay, C.; Rodriguez, M.; Sérodes, J. Using ozonation and chloramination to reduce the formation of trihalomethanes and haloacetic acids in drinking water. Desalination 2005, 176, 229-240. [CrossRef]

42. Hua, G.; Reckhow, D.A. Effect of pre-ozonation on the formation and speciation of DBPs. Water Res. 2013, 47, 4322-4330. [CrossRef] [PubMed]

43. Nieuwenhuijsen, M.J.; Toledano, M.B.; Eaton, N.E.; Fawell, J.; Elliott, P. Chlorination disinfection byproducts in water and their association with adverse reproductive outcomes: A review. Occup. Environ. Med. 2000, 57, 73-85. [CrossRef] [PubMed]

44. Andrzejewski, P.; Kasprzyk-Hordern, B.; Nawrocki, J. The hazard of N-nitrosodimethylamine (NDMA) formation during water disinfection with strong oxidants. Desalination 2005, 176, 37-45. [CrossRef]

45. Hua, G.; Reckhow, D.A. Comparison of disinfection byproduct formation from chlorine and alternative disinfectants. Water Res. 2007, 41, 1667-1678. [CrossRef] [PubMed]

46. De Vera, G.A.; Stalter, D.; Gernjak, W.; Weinberg, H.S.; Keller, J.; Farrè, M.J. Towards reducing DBP formation potential of drinking water by favouring direct ozone over hydroxyl radical reactions during ozonation. Water Res. 2015, 87, 49-58. [CrossRef] [PubMed]

47. Mao, Y.; Wang, X.; Yang, H.; Wang, H.; Xie, Y.F. Effects of ozonation on disinfection byproduct formation and speciation during subsequent chlorination. Chemosphere 2014, 117, 515-520. [CrossRef] [PubMed]

48. Molnar, J.; Agbaba, J.; Dalmacija, B.; Tubic, A.; Krcmar, D.; Maletic, S.; Tomaševic, D. The effects of matrices and ozone dose on changes in the characteristics of natural organic matter. Chem. Eng. J. 2013, 222, 435-443. [CrossRef]

49. Agbaba, J.; Molnar, J.; Tubi, A.; Watson, M.; Maleti, S.; Dalmacija, B. Effects of water matrix and ozonation on natural organic matter fractionation and corresponding disinfection by-products formation. Water Sci. Technol. Water Supply 2015, 15, 75-83. [CrossRef]

50. Richardson, S.D. Disinfection by-products and other emerging contaminants in drinking water. Anal. Chem. 2003, 22. [CrossRef] 
51. Von Gunten, U.; Hoigné, J. Bromate Formation during Ozonation of Bromide-Containing Waters: Interaction of Ozone and Hydroxyl Radical Reactions. Environ. Sci. Technol. 1994, 28, 1234-1242. [CrossRef] [PubMed]

52. Von Gunten, U.; Driedger, A.; Gallard, H.; Salhi, E. By-Products Formation During drinking water Disinfection: A Tool To Assess Disinfection Efficiency? Water Res. 2001, 35, 2095-2099. [CrossRef]

53. Von Gunten, U. Ozonation of drinkingwater: Part II. Disinfection and by-product formation in presence of bromide, iodide or chlorine. Water Res. 2003, 37, 1469-1487. [CrossRef]

54. Andrzejewski, P.; Kasprzyk-Hordern, B.; Nawrocki, J. N-nitrosodimethylamine (NDMA) formation during ozonation of dimethylamine-containing waters. Water Res. 2008, 42, 863-870. [CrossRef] [PubMed]

55. Hollender, J.; Zimmermann, S.G.; Koepke, S.; Krauss, M.; Mcardell, C.S.; Ort, C.; Singer, H.; Von Gunten, U.; Siegrist, H. Elimination of organic micropollutants in a municipal wastewater treatment plan upgraded with a full-scale post-ozonation followed by sand filtration. Environ. Sci. Technol. 2009, 43, 7862-7869. [CrossRef] [PubMed]

56. Gerrity, D.; Owens-Bennett, E.; Venezia, T.; Stanford, B.D.; Plumlee, M.H.; Debroux, J.; Trussell, R.S. Applicability of ozone and biological activated carbon for potable reuse. Ozone Sci. Eng. 2014, 36, 123-137. [CrossRef]

57. Dell'Erba, A.; Falsanisi, D.; Liberti, L.; Notarnicola, M.; Santoro, D. Disinfection by-products formation during wastewater disinfection with peracetic acid. Desalination 2007, 215, 177-186. [CrossRef]

58. Chiang, P.C.; Ko, Y.W.; Liang, C.H.; Chang, E.E. Modeling an ozone bubble column for predicting its disinfection efficiency and control of DBP formation. Chemosphere 1999, 39, 55-70. [CrossRef]

59. U.S. Environmental Protection Agency. Municipal Wastewater Disinfection Design Manual; EPA-625/1-86-021; U.S. Environmental Protection Agency: Cincinnati, OH, USA, 1986.

60. Metcalf \& Eddy. Ingegneria Della Acque Reflue, Trattamento e Riuso; McGraw-Hill: New York, NY, USA, 2006.

61. NESC. Tech Brief. A National Drinking Water Clearinghouse Fact Sheet. Available online: http:/ / www.nesc.wvu.edu/ pdf/dw/publications/ontap/2009_tb/disinfection.June1996dwfsom50.pdf (accessed on 30 December 2017).

62. Environmental Protection Agency (EPA). Water Treatment Manual: Disinfection; EPA: Washington, DC, USA, 2011; ISBN 978-184095-421-0.

63. Masotti, L. Depurazione Della Acque-Tecniche ed Impianti per il Trattamento Delle Acque di Rifiuto; Ed. Calderini: Milano, Italy, 2011; ISBN 978-88-506-5202-0.

64. Water Environment Federation. Design of Municipal Wastewater Treatment Plants. Liquid processes, 4th ed.; WEF Manual of Practice No. 8; American Society of Civil Engineers \& WEF: Reston, VA, USA, 1998; Volume 2, ISBN 0-7844-0342-2.

65. Collivignarelli, M.C.; Abbà, A.; Alloisio, G.; Gozio, E.; Benigna, I. Disinfection in wastewater treatment plants: Evaluation of effectiveness and acute toxicity. Sustainability 2017, 9, 1704. [CrossRef]

66. Tsydenova, O.; Batoev, V.; Batoeva, A. Solar-Enhanced Advanced Oxidation Processes for Water Treatment: Simultaneous Removal of Pathogens and Chemical Pollutants. J. Environ. Res. Public Health 2015, 12, 9542-9561. [CrossRef] [PubMed]

67. Fang, J.; Liu, H.; Shang, C.; Zeng, M.; Ni, M.; Liu, W. E. coli and bacteriophage MS2 disinfection by UV, ozone and the combined UV and ozone processes. Front. Environ. Sci. Eng. 2014, 8, 547-552. [CrossRef]

68. Rodriguez-Chueca, J.; Ormad, M.P.; Mosteo, R.; Sarasa, J.; Ovelleiro, J.L. Conventional and Advanced Oxidation Processes Used in Disinfection of Treated Urban Wastewater. Water Environ. Rese. 2015, 87. [CrossRef]

69. Gilmour, C.R. Water Treatment Using Advanced Oxidation Processes: Application Perspectives. Electronic Thesis and Dissertation Repository. 2012, Volume 836. Available online: http://ir.lib.uwo.ca/etd/836 (accessed on 30 December 2017).

70. Kommineni, S.; Zoeckler, J.; Stocking, A.; Liang, S.; Flores, A.; Kavanaugh, M. 3.0 Advanced Oxidation Processes; National Water Research Institute: Fountain Valley, CA, USA, 2008.

71. U.S. Environmental Protection Agency. Alternative Disinfectants and Oxidants Guidance Manual; EPA 815-R-99-014; U.S. Environmental Protection Agency: Washington, DC, USA, 1999.

72. Crozes, G.; Cushing, R.; Rennecker, J.; Cleveland, C.; Wright, H. Synergies of UV Disinfection and Ozone in Water Treatment; International UV Association: Vienna, Austria, 2003.

73. Berbenni, P.; Chinaglia, V. La disinfezione delle acque con raggi UV; II Giornata di Studio: La Disinfezione delle Acque per uso Potabile; Università degli Studi di Brescia: Brescia, Italy, 1996. 
74. Sarathy, S.; Mohseni, M. An overview of UV-based Advanced Oxidation Processes for drinking water treatment. IUVA News 2006, 8, 16-27.

75. Mamane, H.; Shemer, H.; Linden, K.G. Inactivation of, E. coli, B. subtilis spores, and MS2, T4, and T7 phage using $\mathrm{UV} / \mathrm{H}_{2} \mathrm{O}_{2}$ advanced oxidation. J. Hazard. Mater. 2007, 146, 479-486. [CrossRef] [PubMed]

76. Koivunen, J. Effects of Conventional Treatment, Tertiary Treatment and Disinfection Processes on Hygienic and Physico-Chemical Quality of Municipal Wastewaters; Kuopio University Publications, C. Natural and Environmental Sciences 215: Kuopio, Finland, 2007; ISBN 978-951-27-0788-1.

77. Kruithof, J.C.; Kamp, P.C.; Martijn, B.J. UV $/ \mathrm{H}_{2} \mathrm{O}_{2}$ Treatment: A Practical Solution for Organic Contaminant Control and Primary Disinfection. Ozone Sci. Eng. 2007, 29, 273-280. [CrossRef]

78. Spuhler, D.; Rengifo-Herrera, J.A.; Pulgarin, C. The effect of $\mathrm{Fe}^{2+}, \mathrm{Fe}^{3+}, \mathrm{H}_{2} \mathrm{O}_{2}$ and the photo-Fenton reagent at near neutral $\mathrm{pH}$ on the solar disinfection (SODIS) at low temperatures of water containing Escherichia coli K12. Appl. Catal. B Environ. 2010, 96, 126-141. [CrossRef]

79. Collivignarelli, C.; Sorlini, S. Potabilizzazione Delle Acque. Processi e Tecnologie; Dario Flaccovio: Palermo, Italy, 2009; ISBN 978-88-7758-856-2.

80. Richardson, S.; Thruston, A.; Collette, T.; Patterson, K.; Lykins, B.; Ireland, J. Identification of TiO $2 / \mathrm{UV}^{2}$ Disinfection Byproducts in Drinking Water. Environ. Sci. Technol. 1996, 30, 3327-3334. [CrossRef]

81. Watts, R.J.; Kong, S.; Orr, M.P.; Miller, G.C.; Henry, B.E. Photocatalytic inactivation of coliform bacteria and viruses in secondary wastewater effluent. Water Res. 1995, 29, 95-100. [CrossRef]

82. Chai, Y.; Lee, J.; Kim, B. Photocatalytic Disinfection of E. coli in a Suspended $\mathrm{TiO}_{2} / \mathrm{UV}$ Reactor. Koreans Chem. Eng. 2000, 17, 633-637. [CrossRef]

83. Cho, I.; Moon, L.; Chung, M.; Lee, H.; Zoh, K. Disinfection effects on, E. coli using $\mathrm{TiO}_{2} / \mathrm{UV}$ and solar light system. Water Sci. Technol. 2002, 2, 181-190.

84. Cho, M.; Chung, H.; Choi, W.; Yoon, J. Different Inactivation Behaviors of MS-2 Phage and Escherichia coli in $\mathrm{TiO}_{2}$ Photocatalytic Disinfection. Appl. Environ. Microbiol. 2005, 71, 270-275. [CrossRef] [PubMed]

85. Ottoson, J.; Hansen, A.; Björlenius, B.; Norder, H.; Stenström, T.A. Removal of viruses, parasitic protozoa and microbial indicators in conventional and membrane processes in a wastewater pilot plant. Water Res. 2006, 40, 1449-1457. [CrossRef] [PubMed]

86. Karnik, B.S.; Davies, S.H.; Baumann, M.J.; Masten, S.J. The effects of combined ozonation and filtration on disinfection by-product formation. Water Res. 2005, 39, 2839-2850. [CrossRef] [PubMed]

87. Ribau Teixeria, M.; Joao Rosa, M. Microcystins removal by nanofiltration membranes. Sep. Purif. Technol. 2005, 46, 192-201. [CrossRef]

88. Guidelines for Canadian Drinking Water Quality: Guideline Technical Document-Enteric Protozoa: Giardia and Cryptosporidium. Available online: http://healthycanadians.gc.ca/publications/healthy-living-viesaine/water-protozoa-eau/alt/water-protozoa-eau-eng.pdf (accessed on 30 December 2017).

89. Hai, F.I.; Riley, T.; Shawkat, S.; Magram, S.F.; Yamamoto, K. Removal of Pathogens by Membrane Bioreactors: A Review of the Mechanisms, Influencing Factors and Reduction in Chemical Disinfectant Dosing. Water 2014, 6, 3603-3630. [CrossRef]

90. Jacangelo, J.G.; Trussell, R.R.; Watson, M. Role of membrane technology in drinking water treatment in the United States. Desalination 1997, 113, 119-127. [CrossRef]

91. Caretti, C.; Lubello, C. Wastewater disinfection with PAA and UV combined treatment:a pilot plant study. Water Res. 2003, 37, 2365-2371. [CrossRef]

92. Cotillas, S.; Llanos, J.; Castro-Ríos, K.; Taborda-Ocampo, G.; Rodrigo, M.A.; Canizares, P. Synergistic integration of sonochemical and electrochemical disinfection with DSA anodes. Chemosphere 2016, 163, 562-568. [CrossRef] [PubMed]

93. Birben, N.C.; Tomruk, A.; Bekbolet, M. The role of visible light active $\mathrm{TiO}_{2}$ specimens on the solar photocatalytic disinfection of E. coli. Environ. Sci. Pollut. Res. 2017, 24, 12618-12627. [CrossRef] [PubMed]

94. Naddeo, V.; Landi, M.; Belgiorno, V.; Napoli, R.M.A. Wastewater disinfection by combination of ultrasound and ultraviolet irradiation. J. Hazard. Mater. 2009, 168, 925-929. [CrossRef] [PubMed]

95. Bohrerova, Z.; Shemer, H.; Lantis, R.; Impellitteri, C.A.; Linden, K.G. Comparative disinfection efficiency of pulsed and continuous-wave UV irradiation technologies. Water Res. 2008, 42, 2975-2982. [CrossRef] [PubMed]

96. Verlicchi, P.; Masotti, L. Sistemi Convenzionali e Sistemi Naturali di Disinfezione Delle Acque Reflue; Atti giornata di studio su; Il Ciclo dell'acqua nella pianificazione territoriale: Bologna, Italy, 29 February 2001. 
97. Dullemont, Y.; Visser, A.; Schijven, J.F.; Hiunen, W.A.M. Elimination capacity of slow sand filtration for microorganism determined with spiking experiment. H2O 2004, 37, $22-25$.

98. Dullemont, Y.F.; Schijven, J.F.; Hijnen, W.A.M.; Colin, M.; Magic, A.; Oorthuizen, W. Removal of MS2 Phage, Escherichia coli and Campylobacter lari by Slow sand Filtration; Gimbel, R., Graham, N.J.D., Collins, M.R., Eds.; Recent Progress in Slow Sand and Alternative Biofiltration Process; IWA Publishing: London, UK, 2006.

99. Shijven, J.F.; Hijnen, W.A.M.; Collin, M.; Magic, A.; Oorthuizen, W. Removal of Microorganism by Slow Sand Filtration; RIVM Report 330204001; RIVM: Bilthoven, The Netherlands, 2008.

100. Visser, A.; Hijnen, W.A.M.; Dullemont, Y.; Medema, G.J. Slow sand filters are effective barriers for microorganism. H2O 2004, 37, 26-28.

101. Clasen, T.F. A trial of low-cost ceramic water filters in Bolivia. In Proceedings of the IWA World Water Congress, Marrakech, Morocco, 19-24 September 2004; Workshop 33.

102. Dillon, P.; Pavelic, P.; Page, D.; Beringen, H.; Ward, J. Managed Aquifer Recharge: An Introduction; Waterlines Report Series No. 13; National Water Commission: Canberra, Australia, 2009.

103. Lundth, M.M.A. Managed Aquifer Recharge-A Potential Water Treatment Method in New Zealand? Available online: https://www.waternz.org.nz/Attachment?Action=Download\&Attachment_id=1279 (accessed on 30 December 2017).

104. Liu, L.; Hall, G.; Champagne, P. Effects of environmental factors on the disinfection performance of a wastewater stabilization pond operated in a temperate climate. Water 2016, 8, 5. [CrossRef]

105. Verbyla, M.E.; Mihelcic, J.R. A review of virus removal in wastewater treatment pond systems. Water Res. 2015, 71, 107-124. [CrossRef] [PubMed]

106. Gopal, B.; Goel, U. Competition and Allelopathy in Aquatic Plant Communities. Bot. Rev. 1993, 59, $155-210$. [CrossRef]

107. Raboni, M.; Gavasci, R.; Torretta, V. Assessment of the fate of Escherichia coli in different stages of wastewater treatment plants. Water Air Soil Pollut. 2016, 227, 455. [CrossRef]

108. Kohn, T.; Mattle, M.J.; Minella, M.; Vione, D. A modeling approach to estimate the solar disinfection of viral indicator organisms in waste stabilization ponds and surface waters. Water Res. 2016, 88, 912-922. [CrossRef] [PubMed]

109. Ranjan, K.R.; Kaushik, S.C. Thermodynamic and economic feasibility of solar ponds for various thermal applications: A comprehensive review. Renew. Sustain. Energy Rev. 2014, 32, 123-139. [CrossRef]

110. Kaushika, N.D. Solar ponds: A review. Energy Convers. Manag. 1984, 24, 353-376. [CrossRef]

111. Velmurugan, V.; Srithar, K. Prospects and scopes of solar pond: A detailed review. Renew. Sustain. Energy Rev. 2008, 12, 2253-2263. [CrossRef] 